\title{
Particularities of the Development of Creativeness in Students Through Art Therapy
}

\author{
Ostanov Shuhrat Sharifovich \\ Seniour lecturer of the chair of Pstchology of the Bukhara State university
}

\begin{abstract}
In the following article, the students will have an idea of the selection of theoretical problems of the formation of creativeness attributes through means of Art therapy in young people. In addition, this article presents a theoretical analysis of different views on the issue of creativeness and attitudes.

Keywords: creativeness, creative process, creative thinking, biological potential, psychological potential, harasterological potential, personal experience potential, orientation potential of an individual.
\end{abstract}

\section{INTRODUCTION}

In domestic and foreign Studies, the problem of creativeness is considered within the framework of various conceptions. On the one hand, it is possible to show their dependence, on the other hand, the general tendency to recognize the merits and necessity of revealing the inner dimensions of the psychological phenomenon under study, the laws of activity and development. The analysis of literature shows that in modern psychology there is no single interpretation of the term "creativeness" today. In the scientific studies, many concepts related to creativeness can be found.

Such concepts as creativity, creativity, creativity, heuristics, viable, divergent, lateral thinking, creative abilities, creative activity, creative motivation, self-actualization, self-realization are considered part of the conceptual list associated with the problem of creativity and further the uncertainty and diversity of this concept. Among these concepts, it is expedient to analyze the most famous research to determine the commonality between "creativeness" and creativity, if the interpretation of "creativity" in the description of the formation of the system [1].

REFERENCE REVIEW: Many opinions expressed by foreign authors on the understanding and research of creativeness testify to the possibility and significance of this phenomenon. In the study of creativeness, it is possible to indicate several directions. The first line studies creativeness on the products of flour, that is, the considers the main features of the creative product: quantity, quality and importance. M. Ferson, K. Taylor, D. Taylor and others are supporters of this approach.

The second direction is the study of creativity as a creative process. Any process, including the creative process, has a beginning, a long stretch, a change and, accordingly, some kind of completion. In this case, we can talk about a creative product consisting of an object or ideal (opinion). Therefore, this direction determines and considers the different stages, levels and types of creative thinking process [2].

MAIN PART. The study of the levels of the creative process is closely related to the psychoanalytic direction. Z. Freud described the creative movement as a result of the sublimation of libido energy. Hence, the rationale for the use of pre-emptive techniques for the study of the creative potential of an individual is established [3]. 
The third direction considers creativeness as a previously given ability. K. Simpson's work can be shown as one of the first in this area, which he described creativeness as the ability to abandon stereotyped thinking methods. E.Fromm considered creativity (inventiveness) as the ability to admire and learn, to find solutions in non-standard situations, to discover new things and to deepen one's own experience. Fromm believed that freedom was an aspect of human nature that we either embrace or escape. He observed that embracing our freedom of will was healthy, whereas escaping freedom through the use of escape mechanisms was the root of psychological conflicts. Fromm outlined three of the most common escape mechanisms:

Automaton conformity: changing one's ideal self to conform to a perception of society's preferred type of personality, losing one's true self in the process; Automaton conformity displaces the burden of choice from self to society;

Authoritarianism: giving control of oneself to another. By submitting one's freedom to someone else, this act removes the freedom of choice almost entirely.

Destructiveness: any process which attempts to eliminate others or the world as a whole, all to escape freedom. Fromm said that "the destruction of the world is the last, almost desperate attempt to save myself from being crushed by it".

Within the framework of our study, it is important to consider the work of leading researchers in this area. In foreign psychology J. Gilford and E.Torrens research is distinguished separately. J.Gilford recognized creativeness as a previously given ability, and his experiments are mainly aimed at studying the degree of creativeness diagnostics and the relationship of personality with some cognitive factors. Torrens research is dedicated to studying the dynamics of creativeness. He has interpreted the likelihood of targeted exposure as being focused on developing creativity.

In the fourth direction K.Goldstein, K.Rogers, N.Rogers, A.Maslow and others attributed the creative process to the "self-actualization" of the individual. The creativity of a self-actualized person is like the creativeness of an unbroken child in the impact of culture.

Creativeness is the most basic characteristic of human nature, it is the potential that is given to each person from birth.

Laboratory studies (about animals, children and students) and the artist K. Using examples from the biography of money, K. Stoko argues that strict constraints generalize and point to maintaining high variability that is typical for a highly creative individual. Prohibitions and self-restraint from teachers in childhood affect the expression of creativity, and in adults establish and maintain a high level of variability and creativity. The limitations for childhood talents child are related to the field of education in which teachers reinforce variability, making it a habit [3].

According to the studies conducted by N.F. Vishnyakova, P.F. Kravchuk, Arthur J. Kropli, V.A. Petrovsky, M.Pozdnyakov, S.Yu. Stepanov, E.L.Yakovleva showed that personal capacity is a unique system, consisting of several components (types of capacity):

biological capacity;

psychological potential;

$>$ harasterological capacity;

$>$ personal experience potential;

$>$ orientation potential of the individual;

$>$ creative potential.

$>$ V.A. Molyako listed the following components of the creative potential of the individual [3]:

$>$ aspiring for progress and spiritual growth; 
the ability to be surprised or to fall into confusion when faced with something new or unusual;

$>$ ability to acquire new knowledge quickly;

$>$ ability to fully understand the problem, control its condition;

$>$ spontaneity, addictions;

$>$ spontaneous elasticity;

$>$ originality;

$>$ divergent thinking;

$>$ openness, acceptability with respect to new experience.

J. P. Gilford in his research focused on the qualitative difference between convergent thinking and divergent thinking. Thanks to his work, this topic has come to the attention of researchers and is being discussed in terms of solving problems of practical education [6].

Convergent thinking refers to linear, logical (discursive) thinking, which involves the only correct solution to the problem. Divergent thinking has a completely different direction. In this case, the printsipial capabilities of several solutions come to the fore. "Divergent" consciousness is aimed at finding innovative ways, unconventional ideas.

Also J. Gilford found that there are three main determining factors in the creative thinking process, which are the criteria for creativity. In his opinion, these three main factors of creativity are shown in Figure 1.

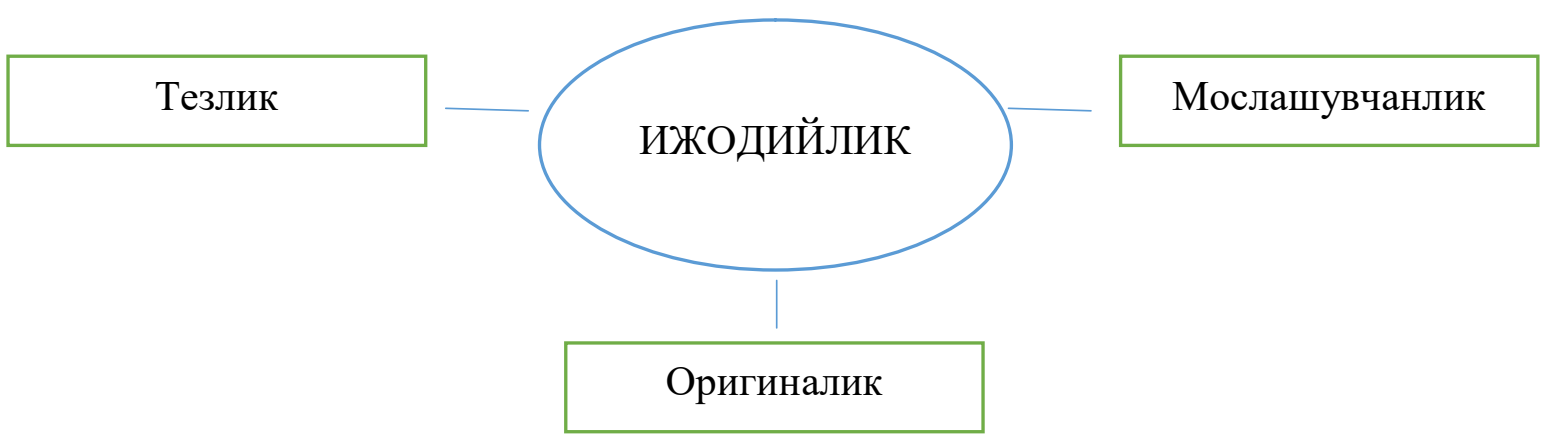

Figure 1. Factors of creativity

The analysis of studies of foreign psychologists revealed a diverse analysis of the concept of creativity. Analyzing the definition given by P. Torrens to the process of creativeness, it can be concluded that "creativeness is a process in which there is sensitivity to problems, discontent with one's own knowledge and a lack of knowledge, the identification of problems, the search for solutions, the formation of hypotheses, its components". Proceeding from these theories, P.Torrens presents the following classification of creativeness:

Figure 1.

\section{P. Torrens' classification of creativity}

\begin{tabular}{|c|l|}
\hline \multicolumn{2}{|c|}{ FACTORS OF COGNITIVE -INTELLECTUAL CREATIVITY } \\
\hline Flexibility of thinking & $\begin{array}{l}\text { Creation of diverse ideas, the multitude of } \\
\text { opinions }\end{array}$ \\
\hline $\begin{array}{c}\text { Usage of the diverse approaches of } \\
\text { adaptable thinking style }\end{array}$ & $\begin{array}{l}\text { Flexibility of thinking is a person's ability to } \\
\text { quickly and easily find new strategies for solving } \\
\text { problems. }\end{array}$ \\
\hline Particularities of thinking & Finding an extraordinary solution \\
\hline Development level of worldview & Harmony of thoughts, logical creative thinking, \\
\hline
\end{tabular}




\begin{tabular}{|c|l|}
\hline \multicolumn{3}{|c|}{ FACTORS OF INDIVIDUAL CREATIVITY } \\
\hline \multirow{2}{|c|}{$\begin{array}{l}\text { the choice of an adequate solution for the } \\
\text { intended purpose. To give a charm to the } \\
\text { solution. }\end{array}$} \\
\hline Inclination to rsiks & $\begin{array}{l}\text { It is determined by the degree of decision- } \\
\text { making in different situations. That is, the } \\
\text { tendency to solve the problem and not to return } \\
\text { from one's own mind, without having enough } \\
\text { knowledge in conspiratorial situations }\end{array}$ \\
\hline Level of complexity & $\begin{array}{l}\text { Always look for an alternative solution. } \\
\text { Understanding the difference between existing } \\
\text { and possible events. Being able to solve difficult } \\
\text { problems and constantly skeptical about } \\
\text { solutions. }\end{array}$ \\
\hline Being interested & $\begin{array}{l}\text { Readiness for constant changes. This is an } \\
\text { interest in acquiring new knowledge, openness } \\
\text { for people, events and the world around them, a } \\
\text { sincere desire to meet the needs of knowledge } \\
\text { and get new experiences or impressions. }\end{array}$ \\
\hline $\begin{array}{l}\text { The fact that a person imagines self-images, new } \\
\text { events and events. To believe in intuition. } \\
\text { Moving away from reality. }\end{array}$ \\
\hline
\end{tabular}

CONCLUSION. On the basis of this study, it is necessary to find out the methodological tools for this problem and to overcome obstacles that hinder the actualization and development of the creative abilities of the individual. In our opinion, as one of such tools, it is possible to come up with a method of art therapy, which is based on art and creative activity.

\section{REFERENCES:}

1. Barotov Sh.R. Psixologik xizmat. Magistrlar uchun darslik. "Durdona" nashriyoti. - Toshkent 2018. - 384 P.

2. Torrance E.P. The nature of creativity as manifest in the testing// R. Sternberg, T. Tardif (eds.). The nature of creativity. Cambridge: Cambr. Press, 1988. P. 43-75.

3. Xomyakov D.S. Problemi kreativnosti. // Aktualniye problemi sovremennoy nauki №6, - M.: «Sputnik +», 2005. - P. 68-71

4. Ostanov Sh.Sh. Role of psychological health of students in the educational process. International Scientific Journal Theoretical \& Applied Science. 2020. Issue: 01. Volume: 81. - P. 443-450.

5. Sh.Sh. Rustamov. Analiz psixologicheskix dannix $\mathrm{s}$ pomoshyu programmi SPSS. Informasionnaya kultura sovremennogo detstva. Sbornik statey Mejdunarodnoy nauchnoprakticheskoy konferensii Rossiya, g. Chelyabinsk, 31 oktyabrya - 1 noyabrya 2019 goda.

6. A.M. Nazarov. The role of temperament in human behavior. International scientific research journal. Volume 2, Issue 5, May, 2021. - P. 60-68. 